\title{
Is animal experimentation fundamental? 1
}

\author{
A experimentação animal é fundamental?
}

\author{
Armando José d'Acampora', Lucas Félix Rossi' ${ }^{\mathrm{II}}$, Jorge Bins Ely ${ }^{\mathrm{II}}$, Zulmar Acciolli de Vasconcellos ${ }^{\mathrm{IV}}$ \\ ${ }^{\mathrm{I}} \mathrm{PhD}$, Head of Operative Technique and Experimental Surgery, UNISUL. Surgeon-in-chief, General Surgery Unit, Florianopolis Hospital, Santa \\ Catarina, Brazil. \\ ${ }^{\text {II } M D, ~ R e s i d e n t, ~ G e n e r a l ~ S u r g e r y, ~ L u t h e r a n ~ U n i v e r s i t y ~ o f ~ B r a z i l ~(U L B R A), ~ P o r t o ~ A l e g r e ~-~ R S, ~ B r a z i l . ~}$ \\ III PhD, Full Professor, Operative Technique and Experimental Surgery, UNISUL. Head of the Operative Technique and Experimental Surgery \\ Laboratory, UFSC, Florianopolis - SC, Brazil. \\ IV PhD, Full Professor, Operative Technique and Experimental Surgery, UFSC, Florianopolis - SC, Brazil.
}

\begin{abstract}
The understanding about the utilization of experimental animals in scientific research and in teaching is many times a complex issue. Special attention needs to be paid to attain the understanding by the general public of the importance of animal experimentation in experimental research and in undergraduate medical teaching. Experimental teaching and research based on the availability of animals for experimentation is important and necessary for the personal and scientific development of the physician-to-be. The technological arsenal which intends to mimic experimentation animals and thus fully replace their use many times does not prove to be compatible with the reality of the living animal. The purpose of this paper is to discuss aspects concerning this topic, bringing up an issue which is complex and likely to arouse in-depth reflections.
\end{abstract}

Key words: Education, Medical, Undergraduate. Research. Models, Animal. Animal Experimentation. Teaching.

\section{RESUMO}

A compreensão a respeito da utilização de animais de experimentação em pesquisas científicas e para o ensino é por vezes matéria intrincada. Especial atenção é necessária em busca do entendimento pela população em geral, da importância da experimentação animal na pesquisa experimental e na graduação em Medicina. $\mathrm{O}$ ensino e a pesquisa experimental na área médica estruturado na disponibilidade de animais para experimentação é importante e necessário para o desenvolvimento pessoal e científico do futuro médico. O arsenal tecnológico que pretende mimetizar os animais de experimentação e com isso substituir totalmente o seu uso muitas vezes não se demonstra compatível com a realidade do animal vivo. Este artigo objetiva expor aspectos concernentes ao tema trazendo à tona o assunto que sem dúvida é complexo e passível de profundas reflexões.

Descritores: Educação de Graduação em Medicina. Pesquisa. Modelos Animais. Experimentação Animal. Ensino.

${ }^{1}$ From Operative Technique and Experimental Surgery Laboratory, University of Southern Santa Catarina (UNISUL) and Federal University of Santa Catarina (UFSC), Brazil.

The utilization of animals in experimentation has been questioned for some time with regards to whether or not it is a fundamental activity for the medical student and for research. We believe that it is, and we base our opinion on three decades of experience in undergraduate medical education and research. Basic training for emergency situations, in which the proper procedure to be adopted is decided, many times depends on previous animal experiments and may save a human life.

The judgment we now make is based on the belief that animals are crucial to teaching and to research, without which we would not achieve so much progress in the medical field, both in prevention as well as in diagnosis and even more so in treatment Nevertheless, a lot of this research has been incorporated to our day-to-day practice and we no longer feel the need to replicate it given the knowledge acquired and the transformation of this knowledge into benefits for mankind, who many times has never even thought of the manufacturing process and the authorization of certain products by humans. So much so that ladies never question whether a certain moisturizing lotion, eyelash mascara or a mere lipstick will cause any damage to the delicate skin of those who use them. That is knowledge incorporated to the daily lives of people and nobody thinks about the issue as it is no longer necessary to do research on animals. That has already been done in the recent past.

In the specific case of animals being used for undergraduate education in Medicine, usually the very first contact of the medical student with the truly living being takes place with the use of animals. That is when the student learns and reinforces the need to have a greater respect for the living being, be it a human or an animal, and the practical trends and skills directly related to surgery are tested in a laboratory of Operative Technique and Experimental Surgery still in the early phases of 
their medical training. That is when most students decide whether they want to become a clinician or a surgeon and that is where they also perceive that most of the time in their future lives they will have to make decisions with greater speed and efficiency, on behalf of life. The process of medical training is on-going and must go through successive stages until it transforms the artisan awakened earlier on in the Operative Technique and Surgical Experimentation laboratory into a full-fledged surgeon.

The importance of the students' contact with animal experimentation during undergraduate training has several nuances to be unveiled by the students themselves and such nuances may take them, in a very near future, to the research field. Aside from allowing the student to enter the rich field of experimental surgery, it also triggers the process of acquiring skills for uncountable procedures. The praxis acquired with the use of experimentation animals, above all within the context of an Operative Technique and Surgical Experimentation laboratory, is of utmost importance in the training of the physician or surgeon-to-be, as they need many of the skills learned in such an environment. We must also realize that most of the time the training of such surgeons-to-be is directly related to an Operative Technique and Surgical Experimentation laboratory. It is in this context that many times the student is inspired by the desire to become a surgeon in the future and this desire ends up shaping the student's professional personality.

However, in the recent years there has been a considerable decrease in the possibility of using experimentation animals to conduct the training of basic surgical practices, for reasons we will not discuss herein. Yet some questions cannot go unasked: "Would we have the evident longevity today if vaccines did not exist?", "How many of us would have already succumbed to malaria, typhoid fever, tuberculosis, smallpox, whooping cough, poliomyelitis, measles, rabies, tetanus, among so many other diseases which affect both the rich and the poor alike?", "Is it not a direct interference in the training of a physician?"

Domenico de Masi calls our attention to the fact that in the mid-nineteenth century, the average lifespan of men was 34 years whereas women lived 35 years in average. The Neandhertal man lived 29 years, only six years less than our great-grandparents. Yet in only two generations the average lifespan of a man has increased 40 years and today a man lives 75 years in average. Thus the question arises: Was that the work of Heaven? Or was it man himself who achieved this victory through research, replicating human events in animals and acquiring knowledge about treatment procedures which did not exist back then?

The use of animal models for research and teaching purposes was established for the very research and test results which led us to the achievement of vaccines, of new techniques, of diagnostic and therapeutic tests. Had it not been for these valuable partners, i.e. the animals used in laboratories, we might not have survived, this is why mankind needs such means of teaching and doing research which should not be extinct. Undoubtedly there is a lot yet to be discovered, since the knowledge about man and life is an on-going process which is fundamental for scientific development.

A practical and palpable example which may easily be proven is the surgery resident who underwent training in Operative Technique and Surgical Experimentation laboratories. The opportunity is usually made available to everyone, but only those interested in surgery take advantage of it and the benefits become obvious when they enter residency in surgery, when they prove to be more skillful both technically as well as in their thinking process as compared to those who did not take such opportunity. The behavior during surgical procedures in humans is different in certain aspects, as it leads to immediate accountability regarding the procedures learned in undergraduate training. In residency, the surgeon-to-be shows greater dexterity and assurance in his or her actions if such previous training was conducted. There is a certain familiarity with the risks and control mechanisms regarding unforeseen events.

Artificial study models in inanimate subjects or even computerized simulators for the teaching of surgery are currently available, however none of these can mimic the complexity of a living organism, as wonderful as they may seem. Tissue consistency, unexpected bleeding in the trans-op period cannot be comparably practiced when a synthetic and or computerized model is used. Besides, such models do not inspire nor do they agree with a basic feeling for a physician to exercise, which is that of compassion.

Moreover, the ethical relationship between humans and animals, which results in the necessary knowledge of bioethics and the principles which guide animal experimentation becomes extremely strengthened when a live subject is used. If animals are no longer used in training the opportunity to acquire knowledge on several concepts becomes frustrated. Experience and, above all, the realism triggered by structured learning with experimentation animals many times cannot be made available to the student through artificial models used for surgical training. The emotions and feelings generated when one has contact with animals are unique moments which may and will have an influence in the personality of the student and future professional, and those feelings shall be demanded by the community in which one is to be inserted.

It is also evident, and one cannot ignore it, that there is a certain social resistance to the use of animals in experimentation. One of the factors which are most often used in the manipulation of public opinion is the distance that exists from death. In the past, all families had a stock of animals for food purposes. Chickens, pigs, ducks, etc. At that time, the existing notion was that suppressing those lives was absolutely necessary to the maintenance of human lives and, hence, accepted without further questioning. With the change in the production processes, animal protein consumed by people comes directly from supermarkets, which "pasteurizes and plasticizes" the death of the millions of animals which are bred and slaughtered daily. This causes a mixture of naiveté and ignorance in those who are easily touched by an ideologically active minority. This minority of activists is formed by a heterogeneous group comprised of people of good faith who truly believe that the progress of biosciences can be achieved other than through experimentation, as well as of those who profit politically and financially through NGO's financed by public money and with very little surveillance, if any. Fortunately, collective consciousness always bears a great deal of common sense and the stunning majority of the population understands the need to use animals, both for food as well as for scientific purposes, with the ultimate purpose of improving the quality of human life. The alternative would be to use human models, which unfortunately has already been done during the Second World War by the nazis.

Finally, it is worthwhile to mention compliance to the 
standards, respect for and abidance to ethical rules, all of which are unquestionable when animals are used in experimentation. However, for their knowledge and dissemination, available animal models are necessary. The discussion about this topic is clearly complex and arouses discussion in the epistemological, social, economic and religious spheres.

One may conclude that the greatest problem presented in animal experimentation, be it in undergraduate training or in research, is the lack of real information provided to the population, not the kind of information which is distorted by exaggeration, that is, experimentation animals are bred to be used in teaching and in research so as to replace human beings in this specific activity. Moreover, one can be assured that there is no pain or disrespect, on the very contrary, we are as much animals as they are, only we bear a few differentiated pairs of chromosomes.

\section{References}

1. d'Acampora AJ. A pesquisa e o Hospital Universitário. Arq Cat Med. 1992;21(4)179-9.
2. d'Acampora AJ. A ciência e o Laboratório de pesquisa. Arq Cat Med. 1994;23(4):229-9.

3. d'Acampora AJ, Correa G. Erro médico. Uma abordagem. Acta Cir Bras. 1996;11(1)42-6.

4. d'Acampora AJ, Cutolo LRA, Schemes KE, Ortellado DK. Um pouco da história e evolução da medicina. Rev Cent Ciênc Saúde. 2002;21(2):40-53. 5. d'Acampora AJ, Cutolo LRA. Seria a doença causa ou conseqüência? Rev Cent Ciênc Saúde. 2002;16(1-2):94-100.

6. d'Acampora AJ. Fazendo e pesquisando a Ciência Médica. Revista on line do GPEB. 2002;1(1):1-4.

7. d'Acampora AJ. Inovar em educação? Arq Cat Med. 2002;31(1-2):1.

8. Utilização de modelos animais em pesquisa. Revista do Conselho Regional de Medicina de Santa Catarina. 2003;92(1):3.

9. d'Acampora AJ. Orquestra sem maestro? Arq Cat Med. 2006;35:2.

10. d'Acampora AJ. Ética? Que ética? Revista do Conselho Regional de Medicina de Santa Catarina. 2007;100:7-8.

11. d'Acampora AJ. A ciência e os animais. Arq Cat Med. 2007;31(1):1.

12. Rossi LF, Ramos RR, Ely JB, Kestering DM, Soldi MS, Brum SP, d'Acampora AJ. Considerations that may influence the result of trials assessing tensile strength in experimental surgery. Acta Cir Bras. 2007;22(6):499-502.

Conflict of interest: none

Financial source: none

\section{Correspondence:}

Armando José d'Acampora

Condomínio San Diego, casa 9

88034-420 Florianopolis - SC Brazil

Received: March 04, 2009

Review: May 06, 2009

Accepted: June 10, 2009

\section{How to cite this article}

d'Acampora AJ, Rossi LF, Ely JB, Vasconcellos ZA. Is animal experimentation fundamental? Acta Cir Bras. [serial on the Internet] 2009 Sept-Oct;24(5). Available from URL: http://www.scielo.br/acb 